\title{
THE EFFECT OF THE TOXEMIAS OF PREGNANCY ON RENAL FUNCTION
}

\author{
By C. A. ELDEN, F. D. SINCLAIR, JR., AND W. C. ROGERS \\ (From the Department of Obstetrics and Gynecology, the University of Rochester School of \\ Medicine and Dentistry, Rochester, New York)
}

(Received for publication February 5, 1936)

In a previous contribution (1) it was shown that there is a wider range of normal values for renal function tests in normal women in the last trimester of pregnancy than in normal non-pregnant individuals. The blood urea clearance (2) was shown to vary between 60 and 118 per cent of normal. The total protein content of the urine was within normal limits. The urinary sediment count of Addis (3) showed the casts to vary from 0 to 10,000 , the red blood cells to range from 47,000 to $1,900,000$ and the white blood and epithelial cells to vary from 25,000 to $6,000,000$. These are the values which must be used for comparison when interpreting the results of renal function tests during the acute phase of the toxemias of pregnancy. When the patient has returned to her normal non-pregnant level, some three months postpartum, comparison can be made with the usual normal values established by Van Slyke and Addis.

The above tests with the routine procedures as previously outlined (1) were made on each of thirty-three patients on three occasions; during the acute phase of the toxemia prior to delivery, in the early puerperium and three or more months postpartum. This method of study was followed in order that the course of renal function could be studied with the possible end in view of an earlier and better prognosis and perhaps a more simple classification of the toxemias of pregnancy. The cases studied have been divided into three groups; (I) preeclampsia including all types from the mild to the more severe; (II) eclampsia; and (III) nephritis complicating pregnancy. The results are shown in Tables I, II and III respectively. The cases in Tables I and II are subdivided into two groups, namely, those with no renal damage and those with possible renal damage.

\section{RESULTS \\ Preeclampsia (Table I)}

This group includes twenty cases of preeclampsia varying from the milder forms with elevated blood pressure and albuminuria to those verging on eclampsia. They are about equally divided between the two subgroups. There was no history of nephritis in any of the cases. In nine of the twenty cases there was a history of a previous preeclampsia. The cases with a history of a previous toxemia are about equally divided between the two subgroups and are identified by an asterisk under the case number. In two of the cases with previous preeclampsia the recent clinical course was sufficiently severe and the renal function sufficiently impaired to warrant termination of the pregnancy. Both of these cases (52767 and 59342) have sustained definite renal injury.

Considering the renal function of this group as a whole it will be noted that during the acute phase the blood urea clearance is for the most part normal. In three cases it was below 60 per cent of normal, the lower normal limit during the last trimester of pregnancy. During the puerperium little change in the blood urea clearance was observed. In the period three or more months postpartum, however, there were four of the nine cases with possible renal damage in which the blood urea clearance was below the lower limits established by Van Slyke. The values obtained were sufficiently low to indicate renal injury.

The degree of proteinuria (4) is of no marked diagnostic or prognostic significance during the acute phase of the toxemia or in the early puerperium. When it is observed in abnormal amounts in the period three months postpartum as it was in three of the nine cases with possible renal damage it serves to indicate renal injury.

The Addis sediment count during the acute phase of the toxemia showed an abnormally high number of casts, erythrocytes, leukocytes and epi- 
thelial cells. The numbers were greatly reduced in the early puerperium but still remained high enough to have pathological significance. During the acute phase and in the early puerperium there was no correlation between the Addis count and the blood urea clearance. In the period three months postpartum the Addis count returned to the normal limits as established by Addis in all cases in the subgroup with no renal damage. In the subgroup with possible renal damage the cast count remained abnormally high in all but two cases and in these two cases the blood urea clearance was below the normal limits established by Van Slyke. In two of the cases in this group the erythrocytes and leukocytes of the urine were above normal.

The results of these observations reveal that of the cases of preeclampsia about half do and half do not show evidence of renal injury three months postpartum. It will be of interest to fol-

TABLE I

Renal function tests in preeclampsia

\begin{tabular}{|c|c|c|c|c|c|c|c|c|c|c|c|}
\hline \multirow{2}{*}{$\begin{array}{c}\text { Case } \\
\text { number }\end{array}$} & \multirow{2}{*}{ Age } & \multirow{2}{*}{ Para } & \multirow{2}{*}{ Days † } & \multirow{2}{*}{$\underset{\text { pressure }}{\text { Blood }}$} & \multicolumn{2}{|c|}{ Urea clearance $\ddagger$} & \multirow{2}{*}{$\begin{array}{c}\text { Protein- } \\
\text { uria }\end{array}$} & \multicolumn{3}{|c|}{ Addis count } & \multirow{2}{*}{ Remarks } \\
\hline & & & & & 1st hour & 2nd hour & & Casts & $\begin{array}{c}\text { Red } \\
\text { blood cells }\end{array}$ & $\begin{array}{c}\text { White } \\
\text { blood cells }\end{array}$ & \\
\hline & years & & & $m m . H g$ & $\begin{array}{c}\text { per cent } \\
\text { of normal }\end{array}$ & $\begin{array}{l}\text { per cent } \\
\text { of normal }\end{array}$ & $\begin{array}{l}\text { grams per } \\
12 \text { hours }\end{array}$ & $\begin{array}{l}\text { thousands } \\
\text { per } 12 \text { hours }\end{array}$ & $\begin{array}{c}\text { millions } \\
\text { per } 12 \text { hours }\end{array}$ & $\mid \begin{array}{c}\text { millions } \\
\text { per } 18 \text { hours }\end{array}$ & \\
\hline
\end{tabular}

NO RENAL DAMAGE

\begin{tabular}{|c|c|c|c|c|c|c|c|c|c|c|c|}
\hline $64985^{*}$ & 27 & 4 & $\begin{array}{r}110 \text { PP } \\
575 \text { PP } \\
130 \text { AP } \\
11 \text { PP }\end{array}$ & $\begin{array}{l}140 / 110 \\
130 / 95 \\
130 / 100\end{array}$ & $\begin{array}{r}146 \mathrm{M} \\
225 \mathrm{M} \\
93 \mathrm{M}\end{array}$ & $\begin{array}{r}207 \mathrm{M} \\
155 \mathrm{M} \\
93 \mathrm{M}\end{array}$ & $\begin{array}{r}.04 \\
.18 \\
\text { Trace }\end{array}$ & $\begin{array}{c}11.6 \\
0 \\
7\end{array}$ & $\begin{array}{l}.14 \\
.27 \\
.64\end{array}$ & $\begin{array}{l}.18 \\
.54 \\
2.3\end{array}$ & Labor induced at term \\
\hline 88160 & 24 & 0 & $\begin{array}{r}12 \mathrm{PP} \\
120 \mathrm{PP}\end{array}$ & $\begin{array}{l}130 / 80 \\
130 / 80\end{array}$ & $\begin{array}{l}93 \mathrm{M} \\
80 \mathrm{M}\end{array}$ & $\begin{array}{r}100 \mathrm{M} \\
70 \mathrm{M}\end{array}$ & $\begin{array}{l}.04 \\
.18\end{array}$ & $\begin{array}{c}13.8 \\
0\end{array}$ & $\begin{array}{l}.50 \\
.08\end{array}$ & $\begin{array}{l}3.6 \Upsilon \\
1.0\end{array}$ & \\
\hline 68626 & 21 & $\mathbf{0}$ & $\begin{array}{r}2 \mathrm{AP} \\
9 \mathrm{PP} \\
100 \mathrm{PP}\end{array}$ & $\begin{array}{l}150 / 100 \\
130 / 80 \\
120 / 90\end{array}$ & $\begin{array}{l}55 \mathrm{~S} \\
80 \mathrm{~S} \\
65 \mathrm{M}\end{array}$ & $\begin{array}{l}36 \mathrm{~S} \\
57 \mathrm{~S} \\
84 \mathrm{M}\end{array}$ & $\begin{array}{l}.75 \\
.8 \\
.02\end{array}$ & $\begin{array}{c}18 \\
49 \\
7.1\end{array}$ & $\begin{array}{l}.04 \\
.02 \\
.02\end{array}$ & $\begin{array}{l}.02 \\
.05 \\
.03\end{array}$ & \\
\hline 73554 & 27 & $\mathbf{0}$ & $\begin{array}{r}31 \mathrm{AP} \\
19 \mathrm{PP} \\
240 \mathrm{PP} \\
180 \mathrm{AP}\end{array}$ & $\begin{array}{l}120 / 70 \\
140 / 90 \\
120 / 60\end{array}$ & $\begin{array}{r}74 \mathrm{M} \\
87 \mathrm{M} \\
105 \mathrm{M}\end{array}$ & $\begin{array}{r}67 \mathrm{M} \\
63 \mathrm{M} \\
105 \mathrm{M}\end{array}$ & $\begin{array}{r}1.03 \\
.04 \\
.18\end{array}$ & $\begin{array}{r}7 \\
18 \\
7\end{array}$ & $\begin{array}{r}.26 \\
1.15 \\
.13\end{array}$ & $\begin{array}{l}4.5 \\
5.7 \\
.39\end{array}$ & Pregnant \\
\hline $29606^{*}$ & 29 & 3 & $\begin{array}{r}3 \text { AP } \\
320 \text { PP }\end{array}$ & $\begin{array}{l}140 / 80 \\
122 / 80\end{array}$ & $\begin{array}{l}132 \mathrm{~S} \\
200 \mathrm{M}\end{array}$ & $\begin{array}{l}104 \mathrm{~S} \\
100 \mathrm{M}\end{array}$ & ${ }_{.15}^{0}$ & $\begin{array}{l}8 \\
0\end{array}$ & $\begin{array}{l}8 \\
.27\end{array}$ & $\begin{array}{l}8 \\
.45\end{array}$ & \\
\hline $27843^{*}$ & 27 & $\mathbf{0}$ & $\begin{array}{r}34 \text { AP } \\
11 \text { PP } \\
185 \text { PP }\end{array}$ & $\begin{array}{l}140 / 90 \\
140 / 98 \\
134 / 80\end{array}$ & $\begin{array}{r}145 \mathrm{M} \\
80 \mathrm{M} \\
84 \mathrm{M}\end{array}$ & $\begin{array}{r}145 \mathrm{M} \\
84 \mathrm{M} \\
66 \mathrm{M}\end{array}$ & $\begin{array}{l}.3 \\
.07 \\
.18\end{array}$ & $\begin{array}{r}18 \\
17 \\
7\end{array}$ & $\begin{array}{l}.14 \\
.31 \\
.13\end{array}$ & $\begin{array}{l}.76 \\
.45 \\
.15\end{array}$ & \\
\hline 72336 & 22 & $\mathbf{0}$ & $\begin{array}{r}1 \text { AP } \\
9 \text { PP } \\
255 \text { PP }\end{array}$ & $\begin{array}{l}150 / 110 \\
120 / 80 \\
128 / 62\end{array}$ & $\begin{array}{l}52 \mathrm{~S} \\
73 \mathrm{~S} \\
82 \mathrm{M}\end{array}$ & $\begin{array}{l}68 \mathrm{~S} \\
89 \mathrm{M} \\
77 \mathrm{M}\end{array}$ & $\begin{array}{r}1.32 \\
1.04 \\
.18\end{array}$ & $\begin{array}{r}150 \\
20 \\
5.3\end{array}$ & $\begin{array}{c}2.8 \\
2.1 \\
30.4 \|\end{array}$ & $\begin{array}{r}3.3 \\
21.8 \text { व } \\
.29\end{array}$ & \\
\hline 66730 & 19 & 0 & $\begin{array}{r}3 \mathrm{AP} \\
97 \mathrm{PP}\end{array}$ & $\begin{array}{c}150 / 100 \\
90 / 50\end{array}$ & $\begin{array}{r}98 \mathrm{M} \\
200 \mathrm{M}\end{array}$ & $\begin{array}{l}76 \mathrm{M} \\
70 \mathrm{M}\end{array}$ & $\begin{array}{l}5.5 \\
.02\end{array}$ & $\begin{array}{l}\S \\
1\end{array}$ & $\begin{array}{l}8 \\
.01\end{array}$ & $\begin{array}{l}8 \\
.04\end{array}$ & \\
\hline $66735^{*}$ & 42 & 11 & $\begin{array}{r}5 \text { AP } \\
11 \text { PP } \\
165 \text { PP }\end{array}$ & $\begin{array}{l}148 / 82 \\
120 / 80 \\
130 / 80\end{array}$ & $\begin{array}{r}100 \mathrm{~S} \\
125 \mathrm{M} \\
80 \mathrm{M}\end{array}$ & $\begin{array}{r}91 \mathrm{M} \\
112 \mathrm{M} \\
81 \mathrm{~S}\end{array}$ & $\begin{array}{c}.1 \\
\text { Trace } \\
.27\end{array}$ & $\begin{array}{c}1.8 \\
47 \\
0\end{array}$ & $\begin{array}{r}.02 \\
22.1 \| \\
.19\end{array}$ & $\begin{array}{c}.04 \\
3.5 \\
.48\end{array}$ & \\
\hline 67966 & 31 & $\mathbf{0}$ & $\begin{array}{r}24 \text { AP } \\
5 \text { AP } \\
9 \text { PP } \\
42 \text { PP }\end{array}$ & $\begin{array}{l}162 / 102 \\
210 / 140 \\
145 / 100 \\
146 / 100\end{array}$ & $\begin{array}{rl}160 & \mathrm{M} \\
77 \mathrm{M} \\
93 \mathrm{M} \\
104 \mathrm{M}\end{array}$ & $\begin{array}{rl}148 & M \\
89 & M \\
81 & M \\
63 & M\end{array}$ & $\begin{array}{c}.52 \\
2.3 \\
.16 \\
.1\end{array}$ & $\begin{array}{l}1.1 \\
24 \\
12 \\
4\end{array}$ & $\begin{array}{l}.21 \\
.37 \\
.12 \\
.016\end{array}$ & $\begin{array}{l}.06 \\
.24 \\
.22 \\
.02\end{array}$ & \\
\hline 71235 & 33 & 5 & $\begin{array}{r}25 \text { AP } \\
9 \text { PP } \\
255 \text { PP }\end{array}$ & $\begin{array}{l}150 / 100 \\
120 / 90 \\
138 / 86\end{array}$ & $\begin{array}{r}74 \mathrm{M} \\
107 \mathrm{M} \\
88 \mathrm{M}\end{array}$ & $\begin{array}{r}82 \mathrm{M} \\
110 \mathrm{M} \\
59 \mathrm{M}\end{array}$ & $\begin{array}{l}.08 \\
.03 \\
.01\end{array}$ & $\begin{array}{r}44 \\
49 \\
0\end{array}$ & $\begin{array}{l}.51 \\
7.0 \\
.29\end{array}$ & $\begin{array}{r}.34 \\
21.7 \pi \\
.66\end{array}$ & \\
\hline
\end{tabular}


TABLE I.-Continued

\begin{tabular}{|c|c|c|c|c|c|c|c|c|c|c|c|}
\hline \multirow{2}{*}{$\begin{array}{c}\text { Case } \\
\text { number }\end{array}$} & \multirow{2}{*}{ Age } & \multirow{2}{*}{ Para } & \multirow{2}{*}{ Days $\uparrow$} & \multirow{2}{*}{$\begin{array}{c}\text { Blood } \\
\text { pressure }\end{array}$} & \multicolumn{2}{|c|}{ Urea clearance $\ddagger$} & \multirow{2}{*}{$\begin{array}{c}\text { Protein- } \\
\text { uria }\end{array}$} & \multicolumn{3}{|c|}{ Addis count } & \multirow{2}{*}{ Remarks } \\
\hline & & & & & 1st hour & 2nd hour & & Casts & $\begin{array}{c}\text { Red } \\
\text { blood cells }\end{array}$ & $\begin{array}{l}\text { White } \\
\text { blood cells }\end{array}$ & \\
\hline & years & & & $m m . H g$ & $\begin{array}{l}\text { per cent } \\
\text { of normal }\end{array}$ & $\begin{array}{l}\text { per cent } \\
\text { of normal }\end{array}$ & $\begin{array}{l}\text { grams per } \\
18 \text { hours }\end{array}$ & $\begin{array}{l}\text { thousands } \\
\text { per } 12 \text { hours }\end{array}$ & $\begin{array}{c}\text { millions } \\
\text { per } 12 \text { hours }\end{array}$ & $\begin{array}{c}\text { millions } \\
\text { per } 12 \text { hours }\end{array}$ & \\
\hline
\end{tabular}

POSSIBLE RENAL INJURY

\begin{tabular}{|c|c|c|c|c|c|c|c|c|c|c|c|}
\hline $52767^{*}$ & 22 & 3 & $\begin{array}{r}24 \mathrm{AP} \\
7 \mathrm{PP} \\
245 \mathrm{PP} \\
555 \mathrm{PP} \\
3 \mathrm{AP}\end{array}$ & $\begin{array}{l}156 / 100 \\
140 / 80 \\
156 / 84 \\
145 / 74\end{array}$ & $\begin{array}{l}190 \mathrm{M} \\
104 \mathrm{M} \\
161 \mathrm{M} \\
130 \mathrm{M}\end{array}$ & $\begin{array}{r}160 \mathrm{M} \\
125 \mathrm{M} \\
149 \mathrm{M} \\
99 \mathrm{M}\end{array}$ & $\begin{array}{l}.26 \\
.16 \\
1.1 \\
.36\end{array}$ & $\begin{array}{r}125 \\
73 \\
52 \\
97\end{array}$ & $\begin{array}{l}2.0 \\
.42 \\
.75 \\
.87\end{array}$ & $\begin{array}{l}1.2 \\
1.8 \\
.56 \\
.70\end{array}$ & $\begin{array}{l}\text { Pregnancy terminated at } \\
\text { term. Sterilized }\end{array}$ \\
\hline 59342* & 38 & 11 & $\begin{array}{r}42 \text { PP } \\
165 \text { PP } \\
5 \text { AP } \\
50 \text { PP } \\
700 \text { PP }\end{array}$ & $\begin{array}{l}260 / 150 \\
250 / 90 \\
220 / 140 \\
190 / 120 \\
230 / 140\end{array}$ & $\begin{array}{c}92 \mathrm{M} \\
135 \mathrm{M} \\
80 \mathrm{~S} \\
\\
60 \mathrm{M}\end{array}$ & $\begin{array}{r}88 \mathrm{M} \\
100 \mathrm{~S} \\
80 \mathrm{~S} \\
\\
50 \mathrm{M}\end{array}$ & .8 & $\begin{array}{l}123 \\
17.8\end{array}$ & $\begin{array}{l}.86 \\
.08\end{array}$ & $\begin{array}{r}3.97 \\
.20\end{array}$ & $\begin{array}{l}\text { Pregnancy terminated at } \\
6 \text { months }\end{array}$ \\
\hline 66142 & 40 & 6 & $\begin{array}{r}14 \mathrm{AP} \\
6 \mathrm{AP} \\
11 \mathrm{PP} \\
65 \mathrm{PP} \\
440 \mathrm{PP}\end{array}$ & $\begin{array}{l}150 / 108 \\
145 / 70 \\
142 / 92 \\
120 / 60 \\
112 / 80\end{array}$ & $\begin{array}{l}73 \mathrm{~S} \\
52 \mathrm{~S} \\
58 \mathrm{M} \\
68 \mathrm{M} \\
54 \mathrm{M}\end{array}$ & $\begin{array}{l}44 M \\
55 \mathrm{~S} \\
45 \mathrm{M} \\
61 \mathrm{M} \\
61 \mathrm{M}\end{array}$ & $\begin{array}{l}.53 \\
.48 \\
.42 \\
.08 \\
.01\end{array}$ & $\begin{array}{r}8 \\
4 \\
2 \\
23 \\
29\end{array}$ & $\begin{array}{l}8 \\
.04 \\
.03 \\
.24 \\
.80\end{array}$ & $\begin{array}{c}8 \\
.04 \\
.09 \\
.18 \\
1.06\end{array}$ & \\
\hline 73692* & 43 & 6 & $\begin{array}{r}5 \mathrm{AP} \\
17 \mathrm{PP} \\
170 \mathrm{PP}\end{array}$ & $\begin{array}{l}140 / 90 \\
110 / 90 \\
110 / 76\end{array}$ & $\begin{array}{r}91 \mathrm{~S} \\
103 \mathrm{~S} \\
98 \mathrm{M}\end{array}$ & $\begin{array}{r}80 \mathrm{~S} \\
155 \mathrm{~S} \\
94 \mathrm{M}\end{array}$ & $\begin{array}{l}.61 \\
.17 \\
.54\end{array}$ & $\begin{array}{r}265 \\
182 \\
35\end{array}$ & $\begin{array}{l}1.8 \\
1.2 \\
.32\end{array}$ & $\begin{array}{r}2.0 \\
.9 \\
.4\end{array}$ & \\
\hline 48129* & 27 & 5 & $\begin{array}{r}1 \mathrm{AP} \\
248 \mathrm{PP}\end{array}$ & $\begin{array}{l}144 / 90 \\
120 / 80\end{array}$ & $\begin{array}{l}132 \mathrm{~S} \\
106 \mathrm{M}\end{array}$ & $\begin{array}{l}171 \mathrm{~S} \\
106 \mathrm{M}\end{array}$ & $\begin{array}{l}.8 \\
.48\end{array}$ & $\begin{array}{l}18 \\
25\end{array}$ & $\begin{array}{l}.92 \\
.05\end{array}$ & $\begin{array}{l}.82 \\
.045\end{array}$ & \\
\hline 76588 & 24 & 0 & $\begin{array}{r}9 \mathrm{PP} \\
450 \mathrm{PP}\end{array}$ & $\begin{array}{l}130 / 80 \\
160 / 110\end{array}$ & $\begin{array}{l}241 \mathrm{M} \\
135 \mathrm{M}\end{array}$ & $\begin{array}{l}143 \mathrm{M} \\
115 \mathrm{M}\end{array}$ & $\begin{array}{c}.05 \\
\text { Trace }\end{array}$ & $\begin{array}{l}15.3 \\
24.9\end{array}$ & $\begin{array}{l}.8 \\
.45\end{array}$ & $\begin{array}{r}3.1 \\
.9\end{array}$ & \\
\hline 84462 & 24 & 0 & $\begin{array}{rl}11 & \mathrm{PP} \\
150 & \mathrm{PP}\end{array}$ & $\begin{array}{l}160 / 105 \\
132 / 86\end{array}$ & $\begin{array}{r}65 \mathrm{M} \\
151 \mathrm{M}\end{array}$ & $\begin{array}{l}61 \mathrm{M} \\
96 \mathrm{M}\end{array}$ & $\begin{array}{l}.36 \\
.18\end{array}$ & $\begin{array}{l}12.3 \\
19.5\end{array}$ & $\frac{\pi}{.87}$ & 1.3 & \\
\hline 40039* & 24 & 3 & $\begin{array}{r}10 \mathrm{PP} \\
120 \mathrm{PP}\end{array}$ & $\begin{array}{l}135 / 90 \\
112 / 70\end{array}$ & $\begin{array}{l}75 \mathrm{~S} \\
69 \mathrm{M}\end{array}$ & $\begin{array}{l}72 \mathrm{M} \\
56 \mathrm{M}\end{array}$ & $\begin{array}{l}\text { Trace } \\
\text { Trace }\end{array}$ & $\begin{array}{l}\mathbf{0} \\
\mathbf{0}\end{array}$ & $\begin{array}{l}.92 \\
.10\end{array}$ & $\begin{array}{l}2.7 \\
.41\end{array}$ & \\
\hline 91845 & 29 & 0 & $210 \mathrm{PP}$ & $115 / 70$ & $77 \mathrm{M}$ & $60 \mathrm{M}$ & .36 & 0 & .41 & 1.6 & \\
\hline
\end{tabular}

$\ddagger M$, Maximum clearance.

$\mathrm{S}$, Standard clearance.

low them through repeated pregnancies in order to learn the effect of repeated toxemias on renal function, should the pregnancy or toxemia occur. The results also show that renal function tests are of no great value in the acute phase of the toxemia or early puerperium so far as diagnosis, prognosis or classification are concerned. They are an aid in prognosis in the period three months postpartum.

\section{Eclampsia (Table II)}

There were six cases of eclampsia, two of which are in the subgroup with no renal damage and four are in the subgroup with possible renal injury. In only one case was there a history of previous preeclampsia. None gave a history of nephritis.

In the acute phase of the toxemia the blood urea clearance was normal in all cases. Too few observations were made in the early puerperium to be of value. However, in the group with renal damage one case had an abnormal clearance and in another the blood urea clearance was normal. In the period three months postpartum all of the cases with no renal damage had a normal blood 
TABLE II

Renal function tests in eclampsia

\begin{tabular}{|c|c|c|c|c|c|c|c|c|c|c|}
\hline \multirow{2}{*}{$\begin{array}{c}\text { Case } \\
\text { number }\end{array}$} & \multirow{2}{*}{ Age } & \multirow{2}{*}{ Para } & \multirow{2}{*}{ Days † } & \multirow{2}{*}{$\begin{array}{l}\text { Blood } \\
\text { pressure }\end{array}$} & \multicolumn{2}{|c|}{ Urea clearance $\ddagger$} & \multirow{2}{*}{$\begin{array}{l}\text { Protein- } \\
\text { uria }\end{array}$} & \multicolumn{3}{|c|}{ Addis count } \\
\hline & & & & & 18t hour & 2nd hour & & Casts & $\begin{array}{l}\text { Red blood } \\
\text { cells }\end{array}$ & $\begin{array}{l}\text { White blood } \\
\text { cells }\end{array}$ \\
\hline & years & & & $m m . H_{8}$ & $\begin{array}{l}\text { per cent } \\
\text { of normal }\end{array}$ & $\begin{array}{c}\text { per cent } \\
\text { of normal }\end{array}$ & $\begin{array}{l}\text { grams per } \\
12 \text { hours }\end{array}$ & $\begin{array}{c}\text { thousands per } \\
18 \text { hours }\end{array}$ & $\begin{array}{l}\text { millions per } \\
18 \text { hours }\end{array}$ & $\begin{array}{l}\text { millions per } \\
12 \text { hours }\end{array}$ \\
\hline \multicolumn{11}{|c|}{ NO RENAL DAMAGE } \\
\hline 65299 & 28 & 3 & $\begin{array}{l}13 \mathrm{AP} \\
90 \mathrm{PP}\end{array}$ & $\begin{array}{l}140 / 96 \\
126 / 80\end{array}$ & $\begin{array}{r}94 \mathrm{M} \\
132 \mathrm{~S}\end{array}$ & $\begin{array}{r}90 \mathrm{M} \\
166 \mathrm{M}\end{array}$ & $\begin{array}{l}.18 \\
.05\end{array}$ & $\begin{array}{l}13 \\
10\end{array}$ & $\begin{array}{l}.03 \\
.11\end{array}$ & $\begin{array}{l}.05 \\
.11\end{array}$ \\
\hline 70284 & 17 & 0 & $\begin{array}{r}0 \\
4 \text { PP } \\
10 \text { PP } \\
125 \text { PP } \\
360 \text { PP }\end{array}$ & $\begin{array}{l}140 / 100 \\
150 / 105 \\
140 / 90 \\
100 / 60 \\
104 / 58\end{array}$ & $\begin{array}{r}190 \mathrm{M} \\
64 \mathrm{~S} \\
103 \mathrm{M} \\
121 \mathrm{M}\end{array}$ & $\begin{array}{r}153 \mathrm{M} \\
107 \mathrm{M} \\
77 \mathrm{M} \\
160 \mathrm{M} \\
69 \mathrm{M}\end{array}$ & $\begin{array}{c}9.96 \\
.89 \\
.27 \\
0 \\
.18\end{array}$ & $\begin{array}{r}2014 \\
46 \\
21 \\
0 \\
0\end{array}$ & $\begin{array}{r}10,541 \\
.58 \\
2.75 \\
.40 \\
1.81\end{array}$ & $\begin{array}{l}7.4 \\
.72 \\
1.6 \\
.1 \\
.27\end{array}$ \\
\hline
\end{tabular}

RENAL DAMAGE

\begin{tabular}{|c|c|c|c|c|c|c|c|c|c|c|}
\hline 43543 & 43 & 5 & $1000 \mathrm{PP}$ & $140 / 90$ & $115 \mathrm{M}$ & $109 \mathrm{M}$ & .2 & 10 & 1.08 & .9 \\
\hline 76931 & 22 & 0 & $\begin{array}{r}8 \text { AP } \\
13 \text { PP } \\
70 \text { PP }\end{array}$ & $\begin{array}{l}210 / 110 \\
130 / 85 \\
140 / 102\end{array}$ & $\begin{array}{l}99 \mathrm{~S} \\
47 \mathrm{M} \\
66 \mathrm{M}\end{array}$ & $\begin{array}{r}112 \mathrm{~S} \\
55 \mathrm{M} \\
61 \mathrm{M}\end{array}$ & $\begin{array}{r}3.24 \\
.36 \\
.18\end{array}$ & $\begin{array}{l}89 \\
26 \\
15\end{array}$ & $\begin{array}{l}8.5 \\
.28 \\
1.65\end{array}$ & $\begin{array}{r}755 \S \\
1.03 \\
16.58\end{array}$ \\
\hline $68108^{*}$ & 24 & 1 & $\begin{array}{rl}1 & \mathrm{AP} \\
11 & \mathrm{PP} \\
160 \mathrm{PP}\end{array}$ & $\begin{array}{l}150 / 100 \\
110 / 90 \\
100 / 75\end{array}$ & $\begin{array}{r}125 \mathrm{M} \\
131 \mathrm{M} \\
59 \mathrm{M}\end{array}$ & $\begin{array}{r}118 \mathrm{M} \\
125 \mathrm{M} \\
72 \mathrm{M}\end{array}$ & $\begin{array}{l}3.3 \\
.41 \\
1.4\end{array}$ & $\begin{array}{r}3636 \\
802 \\
37\end{array}$ & $\begin{array}{r}2.3 \\
1.9 \\
.3\end{array}$ & $\begin{array}{r}7.1 \\
25.0 \\
.75\end{array}$ \\
\hline
\end{tabular}

* History of preeclampsia.

† AP, Antepartum.

PP, Postpartum.

† M, Maximum clearance.

S, Standard clearance.

urea clearance while in the group with possible renal injury all observations save one were below the normal values established by Van Slyke.

The degree of proteinuria is of little significance during the acute phase of the toxemia or in the early puerperium so far as indicating the degree of renal involvement is concerned, since in all cases except two the values obtained in the period three months postpartum were within normal limits.

The Addis count during the acute phase of the toxemia was definitely abnormal in all cases. The number of all formed elements was extremely high in Cases 70284 and 68108, and all varieties of casts were noted. During the early puerperium there was a decrease in the number of
8 Urine infected.

I Trauma to urethra. casts but the number was still abnormal. In the period three months postpartum all of the cases with evidence of renal damage had cast counts above the normal number established by Addis. The erythrocyte, leukocyte and epithelial cell counts were all high in the acute phase. In the period postpartum the red blood cell count remained above the limits of normal in only one case.

As in preeclampsia the tests are of no great value during the acute phase of eclampsia so far as the extent of renal damage is concerned. They are of distinct value in the period three months postpartum, indicating whether or not the kidney has sustained damage. 
Nephritis complicating pregnancy (Table III)

Seven cases of nephritis complicating pregnancy have been observed. Since nephritis complicating pregnancy manifests itself early in gestation the tests are of value in establishing the degree of renal injury. The limits of normal established by Van Slyke and Addis are used for comparison when interpreting the results obtained at this stage of pregnancy.
In the five cases which were terminated early in pregnancy there was subsequently no marked increase in the extent of renal damage. In two of the five cases there was some evidence of improvement. In one of the two cases which was allowed to go to term there was a definite decrease in the values obtained for the blood urea clearance. The other showed no marked change in urea clearance, that she sustained damage, how-

TABLE III

Renal function tests in pregnancy with nephritis

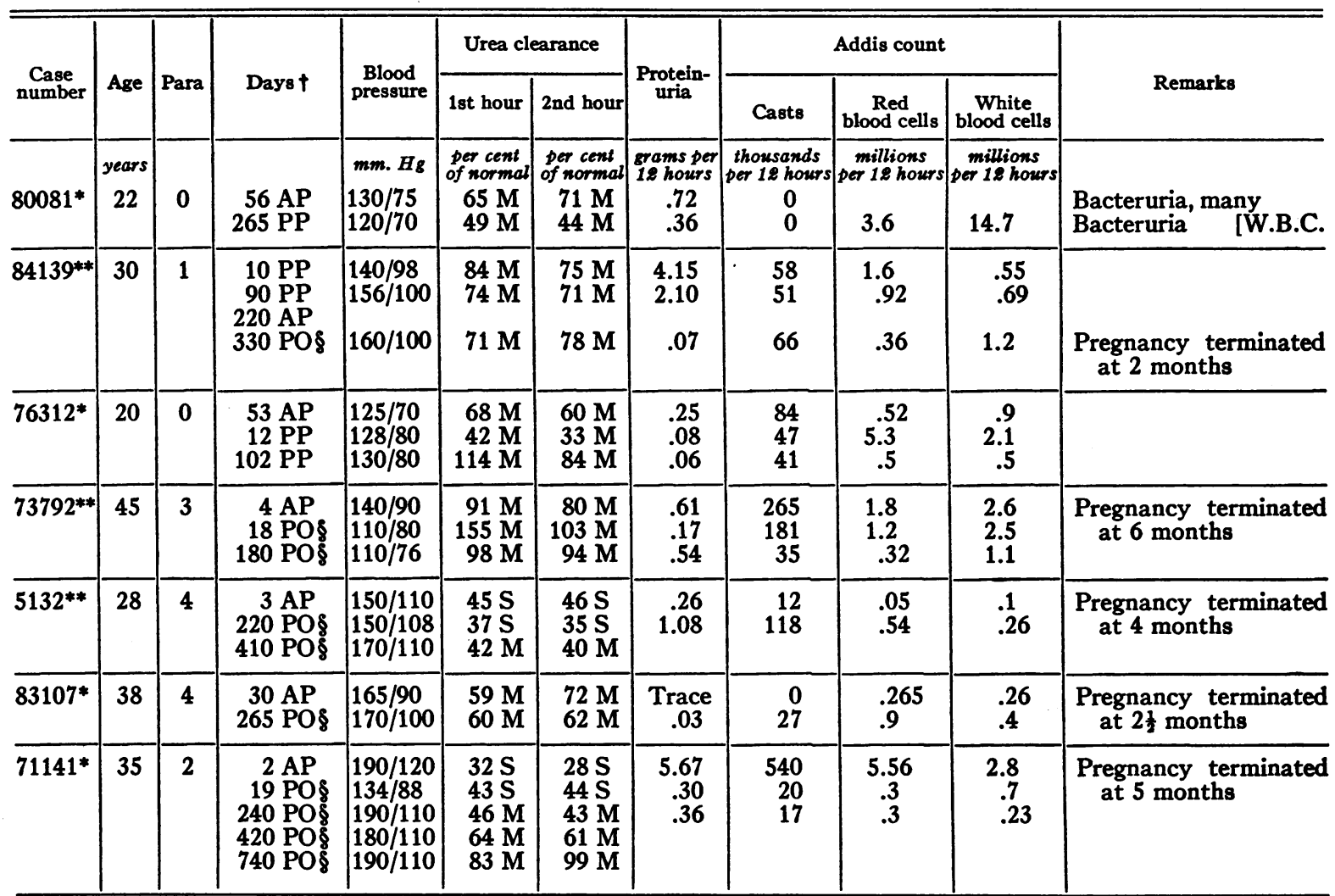

* History of nephritis.

** History of nephritis and preeclampsia.

† AP, Antepartum.

PP, Postpartum.

All of these women gave a history of nephritis and in addition three gave a history of a previous preeclampsia. Pregnancy was terminated early in five of the seven cases. The other two cases were not terminated because in one instance the nephritis was not severe enough and a child was wanted; the other was not terminated because of the patient's refusal.
‡ M, Maximum clearance.

S, Standard clearance.

$\$$ Postoperative.

ever, is indicated by the increase in the number of casts.

\section{DISCUSSION}

The values obtained for the blood urea clearance tests and the Addis urinary sediment count in pregnant women with preeclampsia during the acute phase, prior to delivery and in the early 
puerperium are of little significance so far as diagnosis and treatment are concerned. Three or more months postpartum the patients have apparently returned to the normal state so far as urinary findings and renal function are concerned. Recently Hundley et al. (5) have shown that the dilatation of the ureters and renal pelvis which usually occurs during pregnancy, returns to normal about six weeks postpartum. Three months postpartum the tests are of definite aid in prognosis and as an indication for further treatment. To obtain a better picture of this group of patients it would be necessary to follow them through repeated pregnancies over a period of years should the pregnancy with preeclampsia recur. By this procedure a proper evaluation of the cumulative effects of preeclampsia on renal function could be obtained, providing no intervening infection affecting the kidneys occurred.

In the cases of eclampsia, as in those of preeclampsia, the tests are of value for purposes of diagnosis and treatment only after the three month period postpartum. In those cases which sustain damage the extent seems to be of greater magnitude than in preeclampsia.

In the cases of nephritis complicating pregnancy the renal lesion was not found to have progressed following the early termination of the pregnancy. This is in contrast with the serious damage to the kidneys usually observed when such patients are allowed to go to term. In some of the cases which were terminated early there seems to be some improvement in the renal status. The tests have the same significance in pregnancy complicated by nephritis as in nephritis alone. The normal values established by Van Slyke and Addis were used for comparison in nephritis complicating pregnancy during its early stages.

\section{CONCLUSIONS}

Measurements of the blood urea clearance and counts of the number of formed elements in the urinary sediment were made in thirty-three pregnant women with the various toxemias of pregnancy. The studies were done during the acute phase, in the early puerperium and three or more months postpartum or following operation for the termination of pregnancy. So far we have found the tests to be of no great value during the acute phase and in the early puerperium in cases of preeclampsia and eclampsia, though they have some diagnostic and prognostic significance in the period three months postpartum. In this period it was found that about fifty per cent of the cases of preeclampsia and sixty-seven per cent of the cases of eclampsia had sustained evidence of renal damage. The tests are of value in pregnancy complicated by nephritis, the values observed having the same significance as in nephritis alone. There is no increase in the extent of renal damage following the early termination of pregnancy.

\section{BIBLIOGRAPHY}

1. Elden, C. A., and Cooney, J. W., The Addis sediment count and blood urea clearance test in normal pregnant women. J. Clin. Invest., 1935, 14, 889.

2. Möller, E., McIntosh, J. F., and Van Slyke, D. D., Studies of urea excretion. II. Relationship between urine volume and the rate of urea excretion by normal adults. J. Clin. Invest., 1928, 6, 427.

3. Addis, T., A clinical classification of Bright's disease. J. A. M. A., 1925, 85, 163.

4. Shevky, M. C., and Stafford, D. D., A clinical method for the estimation of protein in urine and other body fluids. Arch. Int. Med., 1923, 32, 222.

5. Hundley, J. M., Jr., Walton, H. J., Hibbits, J. T., Siegel, I. A., and Brack, C. B., Physiologic changes occuring in the urinary tract during pregnancy. Am. J. Obst. and Gynec., 1935, 30, 625. 